\title{
USULAN DESAIN CHECKING FIXTURE DENGAN METODE DESIGN FOR MANUFACTURING AND ASSEMBLY YANG ERGONOMIS
}

\author{
Hanna Setyoningsih', Asep Endih Nurhidayat ${ }^{2}$, Atfal Murodif ${ }^{3}$ \\ 1Jurusan Teknik Industri, Universitas Indraprasta PGRI \\ Email : sesterhanna.ehs@gmail.com \\ 2 Jurusan Teknik Industri, Universitas Indraprasta PGRI \\ Email :a_noerhidayat@yahoo.com \\ 3 Jurusan Teknik Industri, Universitas Indraprasta PGRI \\ Email : atfal1969@gmail.com
}

Masuk : 19-06-2020, revisi : 09-09-2020, diterima untuk diterbitkan : 15-05-2020

\begin{abstract}
ABSTRAK
Sebuah alat kerja yang tidak memenuhi aspek ergonomis dapat menyebabkan letih berlebih hingga cidera ketika digunakan. Akibat dari letih berlebih pada pekerja dapat menurunkan tingkat produktivitas dan merugikan perusahaan. PT. X adalah perusahaaan manufaktur dengan tipe produksi make to order. PT. X mendapat keluhan dari pelanggan yang mengalami cidera otot muskuloskeletal ketika menggunakan alat kerja checking fixture. Checking fixture merupakan satu komponen pendukung dalam proses pembuatan produk yang sangat berpengaruh besar terhadap kualitas produk yang akan dioptimalkan fungsi maupun geometrinya. Penelitian dilakukan untuk menemukan desain checking fixture yang sesuai dengan keinginan pelanggan. Analisis aspek ergonomis akan dilakukan untuk menentukan standar dimensi dalam proses pembuatan desain checking fixture dengan mempertimbangkan beberapa hal diantaranya jarak jangkauan tangan ke locator pin, tinggi checking fixture, posisi berdiri dan posisi genggaman checking fixture. Analisis ergonomi akan dilakukan menggunakan software digital human modeling and simulation. Metode design for manufacturing and assembly digunakan untuk mengetahui biaya yang diperlukan untuk membuat checking fixture. Berdasarkan analisis desain usulan menunjukkan bahwa terjadi perbaikan postur kerja yang ditunjukkan dengan menurunnya nilai PEI dari 2,77 menjadi 0,79 sehingga jumlah produksi mengalami peningkatan menjadi 93 unit. Berdasarkan analisis design for manufacturing and assembly biaya pembuatan checking fixture adalah Rp. 5.145.115.000 per unit.
\end{abstract}

Kata Kunci : Antropometri; Nordic Body Map; Posture Evaluation Index.

\begin{abstract}
A work tool that don't have ergonomic aspects can cause excessive fatigue to injury when used. As a result of excessive fatigue on workers can reduce the level of productivity and harm the company. PT. X is a manufacturing companies with make to order type of production. PT. X received a complaint from a customer who suffered a musculoskeletal muscle injury while using a checking fixture work tool. Checking fixture is a supporting component in the process of making a product that has a great influence on the quality of the product that will be optimized for its function and geometry. The study was conducted to find a checking fixture design that suits the customer's wishes. Ergonomic aspect analysis will be carried out to determine the dimensions of the dimensions in the process of making the design of the checking fixture by considering several things including the distance of the hand's reach to the locator pin, the height of the checking fixture, the standing position and the position of the grip checking fixture. Ergonomics analysis will be conducted using digital human modeling and simulation software. The design for manufacturing and assembly method is used to determine the costs required to make a checking fixture. Based on the analysis of the design, the proposal shows that there is an improvement in the work posture, which is indicated by a decrease in the PEI value from 2.73 to 1.82 so that the number of production has increased to 93 units. Based on the analysis of design for manufacturing and assembly the cost of making the checking fixture is Rp. 5,145,115,000/item.
\end{abstract}

Keywords : Antropometri; Nordic Body Map; Posture Evaluation Index. 


\section{PENDAHULUAN}

\section{Latar Belakang}

Dalam pembuatan body mobil diperlukan sebuah alat bantu kerja untuk mempermudah pekerjaan operator. Alat bantu kerja tersebut adalah checking fixture. Checking fixture membantu komponen/produk dalam pengecekan dimensi dan geometri agar kepresisian produk dapat dicapai dengan maksimal (Hoffman, 1996). Sehingga kegagalan dalam prosses selanjutnya dapat diminimalkan. Proses desain checking fixture sangat berpengaruh terhadap keseluruhan proses produksi. Bentuk desain yang sederhana akan membuat waktu pengerjaan lebih singkat sehingga biaya produksi lebih minim. Selain itu rancangan checking fixture harus memperhatikan nilai ergonomis agar tidak menyebabkan cumulative trauma disorders (CTDs) pada pekerja.

Menurut Susanti L, Zadry. H. R, dan Yuliandra, B. (2015) Cumulative Trauma Disorders (CTDs) adalah sekumpulan gangguan atau kekacauan pada sistem muskuloskeletal (musculosceletal disorders) berupa cedera pada syaraf, otot, tendon, ligamen, tulang dan persendian pada titik-titik ekstrim tubuh bagian atas (tangan, pergelangan, siku dan bahu), tubuh bagian bawah (kaki, lutut, dan pinggul) dan tulang belakang (punggung dan leher). Untuk mencegah terjadinya cidera muskuloskeletal maka dalam membuat suatu alat kerja perlu dilakukan pengukuran antropometri dan Task Analysis Toolkit. Antropometri secara khusus digunakan untuk kepetingan praktik ergonomi, terutama untuk bahan pertimbangan perencanaan produk dari sesuatu barang atau benda, dan sistem kerja manusia dalam melakukan pekerjaan yang berinteraksi dengan lingkungannya (Sunaryo, 2015). Task Analysis Toolkit membantu pengguna untuk melakukan analisis aspek ergonomis dan faktor manusia dalam membuat suatu rancangan benda kerja atau sikap kerja di dunia industri (Siemens Inc, 2008).

\section{Rumusan Masalah}

Berdasarkan hasil evaluasi vendor yang diberikan ke PT. X oleh beberapa perusahaan setiap kali menyelesaikan sebuah proyek, PT. X mendapatkan beberapa feedback negatif bahwa pelanggan kurang puas dengan desain produk yang diberikan karena tidak fungsional dan tidak nyaman untuk digunakan. Untuk dapat mengetahui lebih detail apa saja keluhan dari customer, PT. Karsa Wijaya Pratama telah membagikan Kuesioner dan didapatkan informasi banyaknya keluhan terhadap posisi kerja ketika mengoperasikan checking fixture. Hal ini disebabkan oleh desain checking fixture yang kurang ergonomis.

\section{METODE PENELITIAN}

Metode penelitian yang digunakan dalam penelitian ini adalah metode penelitian kuantitatif karena data yang dikumpulkan berupa angka-angka. Metode penelitian kuantitatif merupakan penelitian yang berdasarkan pada filsafat positivism. Metode ini digunakan dalam meneliti terhadap sampel dan populasi penelitian. Alur penelitian sudah direncanakan sejak awal dan membatasi permasalahan yang ada pada rumusan masalah. Analisis pada metode kuantitatif dapet dilakukan pada tahap akhir sebelum laporan. Data yang telah di dapat akan dianalisis menggunakan beberapa metode serta bantuan software sebagai berikut :

\section{a. Nordic body map}

Metode ini digunakan untuk mengindikasikan tingkat risiko WMSDs yang mungkin dialami oleh pekerja dengan melibatkan secara langsung pekerja dalam pengisian kertas penilaian (Tarwaka, 2011).

b. Uji chi-square

Uji Chi Square digunakan untuk menguji hubungan atau pengaruh dua buah variabel nominal dan mengukur kuatnya hubungan antar variabel ( $C=$ Coefisien of contingency). 
c. Uji pearson

Korelasi Pearson merupakan salah satu ukuran korelasi yang digunakan untuk mengukur kekuatan dan arah hubungan linier dari dua variabel.

\section{d. Task analysis toolkit}

Task analysis toolkit pada software jack 6.0. tools atau metode yang dapat digunakan untuk menganalisis kinerja model manusia virtual dalam penelitian ini berjumlah empat buah, yaitu Static Strength Prediction (SSP), Lower Back Analysis (LBA), Ovako Working Posture Analysis System (OWAS), Rapid Upper Limb Assessment (RULA). Seluruh konfigurasi model manusia virtual yang telah dibuat postur kerjanya akan dianalisis menggunakan keempat metode diatas dan menghasilkan nilai pada tiap tools. Nilai-nilai tersebut akan dihitung menggunakan Posture Evaluation Index (PEI).

\section{e. Antropometri}

Antropometri secara khusus digunakan untuk kepetingan praktik ergonomi, terutama untuk bahan pertimbangan perencanaan produk dari sesuatu barang atau benda, dan sistem kerja manusia dalam melakukan pekerjaan yang berinteraksi dengan lingkungannya.

f. Desain for manufacturing and assembly

merupakan suatu proses perancangan komponen-komponen dengan mempertimbangkan setiap proses yang akan digunakan dalam membuat komponen tersebut guna memastikan bahwa biaya manufakturnya diperkecil (Boothroyd, 2011).

\section{HASIL DAN PEMBAHASAN}

Bagian hasil dan pembahasan merupakan analisis untuk mengetahui rekomendasi desain terbaik untuk PT.X.

\section{Nordic Body Map}

Nordic body map memiliki 27 variabel terhadap rasa sakit pada anggota tubuh selama melakukan pekerjaan. Untuk lebih jelasnya dapat dilihat padda tabel 1. Hasil dari penyebaran kuesioner nordic body map terhadap 20 responden menunjukkan bahwa responden mengalami keluhan rasa sakit pada beberapa bagian tubuh yang dijelaskan pada tabel 2. dan gambar 1 .

Tabel 1. Nordic body map

\begin{tabular}{cl}
\hline No & \multicolumn{1}{c}{ Variabel } \\
\hline 0 & Sakit pada atas leher \\
\hline 1 & Sakit pada bawah leher \\
\hline 2 & Sakit pada kiri bahu \\
\hline 3 & Sakit pada kanan bahu \\
\hline 4 & Sakit pada kiri atas lengan \\
\hline 5 & Sakit pada punggung \\
\hline 6 & Sakit pada kanan atas lengan \\
\hline 7 & Sakit pada pinggang \\
\hline 8 & Sakit pada pantat \\
\hline 10 & Sakit pada bagian bawah pantat \\
\hline 11 & Sakit pada kiri siku \\
\hline 12 & Sakit pada kanan siku \\
\hline
\end{tabular}




\begin{tabular}{ll}
13 & Sakit pada kanan lengan bawah \\
\hline 14 & Sakit pada pergelangan tangan kiri \\
\hline 15 & Sakit pada pergelangan tangan kanan \\
\hline 16 & Sakit pada tangan kiri \\
\hline 17 & Sakit pada tangan kanan \\
\hline 18 & Sakit pada paha kiri \\
\hline 20 & Sakit pada paha kanan \\
\hline 21 & Sakit pada lutut kiri \\
\hline 22 & Sakit pada lutut kanan \\
\hline 23 & Sakit pada betis kiri \\
\hline 24 & Sakit pada betis kanan \\
\hline 25 & Sakit pada pergelangan kaki kanan \\
\hline 26 & Sakit pada kaki kiri \\
\hline 27 & Sakit pada kaki kanan \\
\hline & Sumber tabel : Penulis, 2020
\end{tabular}

Setelah melakukan rekap hasil kuesioner maka segera dilakukan perhitungan rhitung, dimana: Kesimpulan :

Rhitung $>$ Rtabel maka dinyatakan valid.

$$
\begin{aligned}
\mathrm{df} & =\text { Jumlah responden }-2 \\
& =20-2=18 \\
\alpha & =5 \%=0,05 \\
& =0,378 \text { (rtabel) }
\end{aligned}
$$

Tabel 2. Hasil kuesioner nordic body map

\begin{tabular}{cccccccc}
\hline & \multicolumn{2}{c}{ Kriteria } & rhitung & & rtabel & $\%$ & Anggota Tubuh \\
\hline Korelasi & X1 & terhadap total : & 0.446 & $>$ & 0.378 & $45 \%$ & Leher Bawah \\
\hline Korelasi & X3 & terhadap total : & 0.526 & $>$ & 0.378 & $53 \%$ & Bahu Kanan \\
\hline Korelasi & X5 & terhadap total : & 0.491 & $>$ & 0.378 & $49 \%$ & Punggung \\
\hline Korelasi & X7 & terhadap total : & 0.484 & $>$ & 0.378 & $48 \%$ & Pinggang \\
\hline Korelasi & X20 & terhadap total : & 0.499 & $>$ & 0.378 & $50 \%$ & Lutut Kiri \\
\hline Korelasi & X21 & terhadap total : & 0.499 & $>$ & 0.378 & $50 \%$ & Lutut Kanan \\
\hline Korelasi & X23 & terhadap total : & 0.492 & $>$ & 0.378 & $49 \%$ & Betis Kanan \\
\hline Korelasi & X24 & terhadap total : & 0.498 & $>$ & 0.378 & $50 \%$ & Pergelangan Kaki Kiri \\
\hline Korelasi & X25 & terhadap total : & 0.482 & $>$ & 0.378 & $48 \%$ & Pergelangan Kaki Kanan \\
\hline Korelasi & X26 & terhadap total : & 0.456 & $>$ & 0.378 & $46 \%$ & Telapak Kaki Kiri \\
\hline Korelasi & X27 & terhadap total : & 0.360 & $>$ & 0.378 & $36 \%$ & Telapak Kaki Kanan \\
\hline
\end{tabular}

Sumber tabel : Penulis, 2020

Untuk mempermudah dalam membaca hasil kuesioner maka dibuat grafik pengelompokkan rhitung > rtabel dalam gambar 1. dibawah ini. 


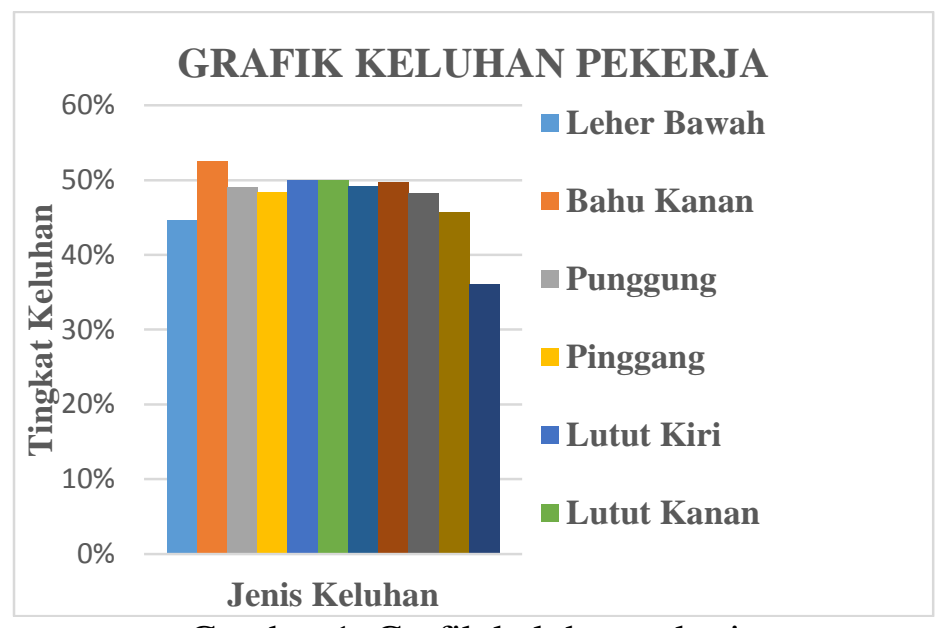

Gambar 1. Grafik keluhan pekerja

Sumber : Penulis, 2020

\section{Uji Chi-square}

Penyebaran kuesioner dampak kerja bertujuan untuk mempertegas bahwa desain checking fixture saat ini sudah sesuai atau belum dengan kebutuhan penggunanya serta untuk melihat hubungan antara desain dengan ukuran antropometri yang akan diusulkan oleh penulis. Pada kuesioner dampak kerja terdapat sepuluh pernyataan yang sudah dijawab oleh 20 responden dan sudah di rekap pada tabel 4. dibawah ini.

Tabel 3. Kuesioner dampak kerja

Sumber : Penulis, 2020

\begin{tabular}{cl}
\hline \multicolumn{1}{c}{ No } & \multicolumn{1}{c}{ Variable } \\
\hline Alat bantu kerja & \multicolumn{1}{c}{$\begin{array}{l}\text { Sikap kerja pada saat melakukan pengecekan part mobil } \\
\text { terasa nyaman }\end{array}$} \\
\hline 1 & $\begin{array}{l}\text { Tinggi rendahnya alat checking fixture saat ini dapat } \\
\text { disesuaikan dengan kebutuhan pengguna }\end{array}$ \\
\hline 2 & $\begin{array}{l}\text { Alat checking fixture mudah untuk dipindahkan seorang } \\
\text { diri }\end{array}$ \\
\hline 3 & Alat checking fixture memiliki bobot kurang dari 15kg \\
\hline 4 & $\begin{array}{l}\text { Alat } \text { checking fixture mudah dijangkau oleh tangan dari } \\
\text { segala sisi }\end{array}$ \\
\hline 5 & Alat checking fixture memiliki hand grip \\
\hline 6 & $\begin{array}{l}\text { Part mobil mudah di bongkar pasang pada alat checking } \\
\text { fixture }\end{array}$ \\
\hline 7 & $\begin{array}{l}\text { Menggunakan alat checking fixture dapat dari berbagai } \\
\text { posisi kerja }\end{array}$ \\
\hline 9 & $\begin{array}{l}\text { Kaki tidak mengalami kesemutan atau kebas jika } \\
\text { menggunakan alat checking fixture secara berkala }\end{array}$ \\
\hline 10 & Tubuh bagian atas tidak mengalami rasa letih berlebih \\
\hline Dampak pekerjaan & Desain checking fixture saat ini dirasa masih kurang sesuai \\
\hline 1 & $\begin{array}{l}\text { Rasa sakit pada anggota tubuh tertentu menyebabkan } \\
\text { pekerjaan terganggu }\end{array}$ \\
\hline
\end{tabular}


Tabel 4. Data kuesioner dampak kerja Sumber : Penulis, 2020

\begin{tabular}{ccc}
\hline Pernyataan & Ya & Tidak \\
\hline 1 & 2 & 18 \\
\hline 2 & 0 & 20 \\
\hline 3 & 3 & 17 \\
\hline 4 & 0 & 20 \\
\hline 5 & 17 & 3 \\
\hline 6 & 0 & 20 \\
\hline 7 & 20 & 0 \\
\hline 8 & 3 & 17 \\
\hline 9 & 2 & 18 \\
\hline 10 & 2 & 18 \\
\hline
\end{tabular}

Dapat dilihat pada tabel 4 . bahwa pernyataan $1,3,5,8,9,10$, tidak memenuhi aspek ergonomi menurut para responden, maka penulis akan menfokuskan kepada pernyataan tersebut untuk melakukan perbaikan desain. Pernyataan akan dihitung menggunakan aplikasi SPSS untuk melakukan uji chi square dan uji korelasi pearson. Uji chi square dilakukan untuk mengetahui ubungan antara keluhan yang dirasakan responden dengan desain checking fixture. Jika nilai asymp. Sig lebih < 0,05 maka terdapat hubungan antara kedua variabel dan memiliki korelasi.

\begin{tabular}{|c|c|c|c|c|c|}
\hline \multicolumn{6}{|c|}{ Chi-Square Tests } \\
\hline & Value & df & $\begin{array}{l}\text { Asymptotic } \\
\text { Significance } \\
\text { (2-sided) }\end{array}$ & $\begin{array}{l}\text { Exact Sig. (2- } \\
\text { sided) }\end{array}$ & $\begin{array}{l}\text { Exact Sig. (1- } \\
\text { sided) }\end{array}$ \\
\hline Pearson Chi-Square & $4.127^{\mathrm{a}}$ & 1 & .042 & & \\
\hline Continuity Correction ${ }^{b}$ & 1.563 & 1 & .211 & & \\
\hline Likelihood Ratio & 4.628 & 1 & .031 & & \\
\hline Fisher's Exact Test & & & & .111 & .111 \\
\hline $\begin{array}{l}\text { Linear-by-Linear } \\
\text { Association }\end{array}$ & 3.921 & 1 & .048 & & \\
\hline $\mathrm{N}$ of Valid Cases & 20 & & & & \\
\hline
\end{tabular}

a. 2 cells $(50.0 \%)$ have expected count less than 5 . The minimum expected count is .70 .

b. Computed only for a $2 \times 2$ table

Gambar 2. Pernyataan ke-1

Sumber : Penulis, 2020

Gambar 2. Menunjukkan nilai asymp. Sig 0,002<0,05 maka dapat disimpulkan bahwa "terdapat hubungan antara pernyataan ke-1 dengan desain yang tidak ergonomis " hal ini dapat diartikan pula bahwa sikap kerja seseorang mempunyai korelasi dengan desain checking fixture saat ini. 
Tabel 5. Chi-square seluruh pernyataan

Sumber: Penulis, 2020

\begin{tabular}{lcc}
\hline \multirow{2}{*}{\multicolumn{1}{c}{ Pernyataan }} & \multicolumn{2}{c}{ Asymp. Sig } \\
\cline { 2 - 3 } & Desain & Rasa sakit \\
\hline Usia & 0.888 & 0.822 \\
\hline Masa kerja & 0.848 & 0.648 \\
\hline Pendidikan & 0.124 & 0.855 \\
\hline Status pernikahan & 0.639 & 0.264 \\
\hline Riwayat penyakit & 0.639 & 0.264 \\
\hline Pernyataan ke-1 & 0.042 & 0.264 \\
\hline Pernyataan ke-3 & 0.052 & 0.028 \\
\hline Pernyataan ke-5 & 0.948 & 0.348 \\
\hline Pernyataan ke-8 & 0.043 & 0.043 \\
\hline Pernyataan ke-9 & 0.01 & 0.028 \\
\hline Pernyataan ke-10 & 0.01 & 0.028 \\
\hline
\end{tabular}

Pernyataan yang memiliki korelasi dengan keluhan rasa sakit dan ketidaksesuaian desain adalah pernyataan ke 1,3,8, 9 dan 10. Pernyataan ke-1 memiliki nilai 0,042<0,05 maka terdapat hubungan antara pernyataan ke-1 dengan desain yang tidak ergonomis. Pernyataan ke-3 memiliki nilai 0,028 $<0,05$ maka terdapat hubungan antara pernyataan ke-3 dengan rasa sakit yang dialami pekerja. Pernyataan ke-8 memiliki nilai $0,0423<0,05$ maka terdapat hubungan antara pernyataan ke-8 dengan desain yang tidak ergonomis dan rasa sakit yang dialami pekerja. Pernyataan ke-9 memiliki nilai $0,01<0,05$ maka terdapat hubungan antara pernyataan ke- 9 dengan desain yang tidak ergonomis dan rasa sakit yang dialami pekerja. Pernyataan ke-10 memiliki nilai 0,01<0,05 maka terdapat hubungan antara pernyataan ke-10 dengan desain yang tidak ergonomis dan rasa sakit yang dialami pekerja.

\section{Uji Pearson}

Uji pearson ini dilakukan untuk mengetahui tingkat keeratan hubungan antara variabel yang dinyatakan, jika nilai signifikansi $<0,05$ maka berkolerasi.

Correlations

\begin{tabular}{llrr} 
& & & \multicolumn{2}{c}{$\begin{array}{c}\text { Dampak } \\
\text { Kerja }\end{array}$} \\
\hline Desain & Pearson Correlation & 1 & $.545^{\star}$ \\
\cline { 2 - 4 } & Sig. (2-tailed) & & .013 \\
\cline { 2 - 4 } Dampak Kerja & Pearson Correlation & $.545^{\star}$ & 20 \\
\cline { 2 - 4 } & Sig. (2-tailed) & .013 & 1 \\
\cline { 2 - 4 } & $\mathrm{N}$ & 20 & 20 \\
\hline
\end{tabular}

*. Correlation is significant at the 0.05 level (2-tailed).

Gambar 3. Uji Pearson

Sumber : Penulis, 2020 
a. Nilai signifikansi

Maka :

Karena nilai signifikansi $0,013<0,05$ maka berkolerasi sehingga daoat dikatakan bahwa terdapat hubungan antara desain checking fixture dengan keluhan dampak kerja.

b. Pedoman derajat hubungan

Nilai pearson korelasi $0,41 \mathrm{~s} / \mathrm{d}$ 0,60 $=$ korelasi sedang.

Karena nilai pearson korelasi 0,545 maka hubungan desain checking fixture dan keluhan dampak kerja berada dalam kategori sedang.

c. Perbandingan korelasi pearson dengan $r$ tabel

Jika nilai korelasi pearson $>\mathrm{r}$ tabel $=$ berhubungan

Nilai korelasi pearson 0,545 $>0,444=$ berhubungan, maka terdapat hubungan antara variabel desain chceking fixture dengan keluhan dampak kerja.

\section{Task Analysis Toolkit}

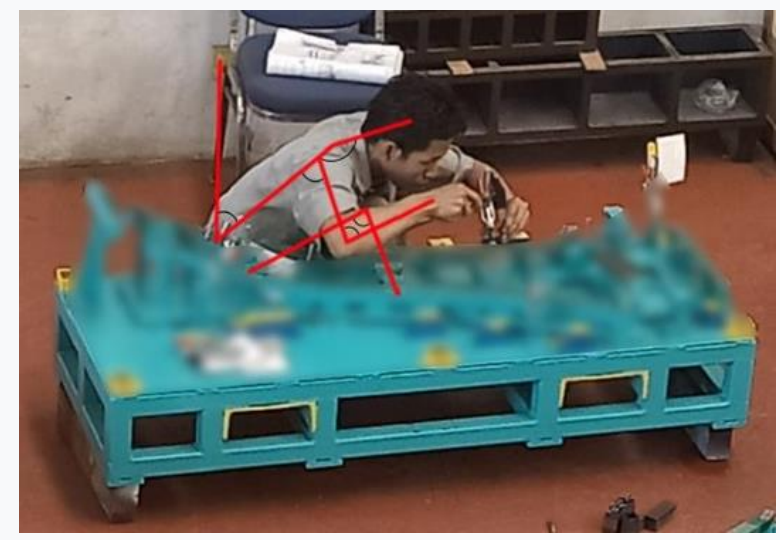

Gambar 4. Postur kerja sebelum perbaikan Sumber : PT. X

Gambar diatas menunjukkan postur kerja penggunaan checking fixture sebelum perbaikan. Setelah dilakukan analisis Static Strength Prediction (SSP), Lower Back Analysis (LBA), Ovako Working Posture Analysis System (OWAS), Rapid Upper Limb Assessment (RULA) maka didapatkan hasil sebagai berikut ini :

Tabel 6. Task Analysis Toolkit Sebelum perbaikan

Sumber : Penulis, 2020

\begin{tabular}{lccc}
\hline Postur Tubuh & Nilai LBA & Nilai OWAS & Nilai Rula \\
\hline Memasang part mobil pada checking fixture & 1544 & 4 & 7 \\
\hline Memindahkan checking fixture & 1657 & 3 & 7 \\
\hline
\end{tabular}

dapat diketahui bahwa skor RULA adalah 7 poin, berarti postur kerja yang dilakukan tidak aman, sehingga harus ada sebuah perbaikan pada desain. Desain checking fixture yang terlalu rendah membuat kaki pekerja menekuk dan punggung membungkuk. Hasil evaluasi postur kerja dengan metode OWAS pada kondisi aktual operator checking fixture menunjukkan bahwa postur kerja operator berada dalam kondisi berbahaya yang dapat menyebabkan stress pada tubuh serta cidera musculoskeletal pada operator jika terus dilakukan. Skor nilai OWAS berada pada critical posture dengan skor 3 dan 4. Nilai LBA yang didapatkan sebesar 1494 N karena postur kerja operator tersebut cenderung membungkuk kedepan. 
Untuk mendapatkan nilai PEI harus menjumlahkan tiga buah variabel I1, I2, dan I3. Dimana variabel I1 adalah nilai LBA/3400 N, I2 adalah nilai OWAS/4, dan I3 adalah nilai (Rula/7)*Mr. Mr adalah amplification factor dengan nilai 1,42 (Caputo, 2006).

Tabel 7. Nilai PEI Sebelum Usulan

Sumber: Penulis, 2020

\begin{tabular}{lcccc}
\hline Postur Tubuh & Nilai LBA & Nilai OWAS & Nilai Rula & Nilai PEI \\
\hline Memasang part mobil pada checking fixture & 0.4541176 & 1 & 1.42 & 2.87 \\
\hline Memindahkan checking fixture & 0.4873529 & 0.75 & 1.42 & 2.66 \\
\hline \multicolumn{2}{c}{ Rata-rata } & & 2.77 \\
\hline
\end{tabular}

\section{ANTROPOMETRI}

Pengukuran antropometri dilakukan terhadap 20 responden anggota tubuh yang diukur adalah tinggi badan berdiri, tinggi bahu berdiri, tinggi siku, tinggi pinggul, dan rentang tangan. Berdasarkan responden yang berjumlah 20 orang maka didapatkan persentil berdasarkan letak sebagai berikut :

Tabel 8. Persentil berdasarkan letak Sumber : Penulis, 2020

\begin{tabular}{lc}
\hline Persentil berdasarkan letak : & $\mathbf{p}(\mathbf{n}) \mathbf{n} / \mathbf{1 0 0} * \mathbf{N}$ \\
\hline $\mathrm{p}(5)=5 / 100 * 20=$ & 1 \\
\hline $\mathrm{p}(50)=50 / 100 * 20=$ & 10 \\
\hline $\mathrm{p}(95)=95 / 100 * 20=$ & 19 \\
\hline
\end{tabular}

Tabel 9. Data ukuran tubuh responden

Sumber : Penulis, 2020

\begin{tabular}{cccccc}
\hline Sampel Ke & Tinggi Badan Berdiri & Tinggi Bahu Berdiri & Tinggi Siku & Tinggi Siku Berdiri & Rentang Tangan Ke Depan \\
\hline 1 & 165 & 138 & 98 & 98 & 70 \\
\hline 2 & 169 & 140 & 102 & 102 & 72 \\
\hline 3 & 166 & 136 & 95 & 95 & 78 \\
\hline 4 & 170 & 138 & 103 & 103 & 71 \\
\hline 5 & 165 & 139 & 101 & 101 & 73 \\
\hline 6 & 171 & 143 & 103 & 103 & 72 \\
\hline 7 & 169 & 140 & 102 & 102 & 75 \\
\hline 8 & 167 & 139 & 105 & 105 & 74 \\
\hline 9 & 173 & 143 & 104 & 104 & 78 \\
\hline 10 & 172 & 139 & 99 & 99 & 68 \\
\hline 11 & 171 & 140 & 107 & 107 & 71 \\
\hline 12 & 172 & 140 & 95 & 95 & 70 \\
\hline 13 & 173 & 141 & 101 & 101 & 72 \\
\hline 14 & 170 & 140 & 100 & 100 & 73 \\
\hline 15 & 169 & 142 & 102 & 102 & 74 \\
\hline 16 & 172 & 138 & 102 & 102 & 73 \\
\hline 17 & 172 & 142 & 104 & 104 & 77 \\
\hline 18 & 173 & 143 & 103 & 103 & 70 \\
\hline 19 & 174 & 144 & 106 & 106 & 98 \\
\hline 20 & 168 & 138 & 98 & & 73 \\
\hline
\end{tabular}


Setelah diketahui persentil berdasarkan letak maka berikutnya dicari persentil berdasarkan nilai. Persentil ini akan digunakan untuk menentukan ukuran dimensi rancangan checking fixture.

Tabel 10. Persentil berdasarkan nilai

Sumber : Penulis, 2020

\begin{tabular}{lccc}
\hline \multirow{2}{*}{ Persentil berdasarkan nilai : } & \multicolumn{2}{c}{$\mathbf{P} \mathbf{i}=\mathbf{b}+\mathbf{p}\left[\left(\left(\mathbf{i}^{*} \mathbf{N}\right) / \mathbf{1 0 0}-\mathbf{F}\right) / \boldsymbol{f}\right.$} \\
\cline { 2 - 4 } & P_5 & P_50 & P_95 \\
\hline Tinggi badan berdiri & 165,56 & 168,80 & 172,60 \\
\hline Tinggi bahu berdiri & 137,51 & 138,79 & 142,08 \\
\hline Tinggi siku berdiri & 96,13 & 100,50 & 107,43 \\
\hline Tinggi pinggul & 95,07 & 98,70 & 101,88 \\
\hline Rentang tangan & 68,94 & 71,46 & 78,34 \\
\hline
\end{tabular}

\section{Analisa Desain Checking Fixture}

Desain usulan checking fixture dibuat seperti meja yang dilengkapi dengan roda serta pegangan agar mudah saat melakukan pemindahan. Checking fixture di desain seperti meja untuk menghindari posisi kerja jongkok saat mengecek part mobil. Berikut ini adalah data dari spesifikasi checking fixture usulan.

Tabel 11. Daftar kebutuhan desain

Sumber : Penulis, 2020

\begin{tabular}{|c|c|c|c|c|}
\hline No & Daftar Kebutuhan & Usulan Perubahan Desain & Peningkatan yang di dapat & Objek \\
\hline 1 & Checking Fixture Terlalu Rendah & $\begin{array}{l}\text { Membuat dolly untuk } \\
\text { menambah ketinggian } \\
\text { checking fixture }\end{array}$ & $\begin{array}{l}\text { Operator tidak perlu } \\
\text { membungkuk saat bekerja } \\
\text { sehingga memaksimalkan } \\
\text { optimasi produksi }\end{array}$ & Dolly \\
\hline 2 & Checking Fixture Terlalu Berat & $\begin{array}{l}\text { membuat checking } \\
\text { fixture dari bahan yang } \\
\text { lebih ringan }\end{array}$ & $\begin{array}{l}\text { untuk mengangkat } \\
\text { checking fixture tidak } \\
\text { memerlukan tenaga dari } 2 \\
\text { orang, sehingga dapat } \\
\text { melakukan efisiensi } \\
\text { operator }\end{array}$ & Necuron \\
\hline 3 & Checking Fixture Sulit Dipindahkan & $\begin{array}{l}\text { menambahkan roda pada } \\
\text { kaki checking fixture }\end{array}$ & $\begin{array}{l}\text { pemindahan checking } \\
\text { fixture menjadi lebih } \\
\text { mudah sehingga } \\
\text { memperpendek waktu } \\
\text { siklus produk dan } \\
\text { menghemat ruang }\end{array}$ & Roda \\
\hline
\end{tabular}

Untuk ukuran tinggi checking fixture menggunakan tinggi siku berdiri P50 dan lebar checking fixture menggunakan rentang tangan P5.
a. Tinggi checking fixture : $573 \mathrm{~mm}$
b. Panjang checking fixture : $1100 \mathrm{~mm}$
c. Lebar checking fixture : $600 \mathrm{~mm}$
d. Diameter handle $\quad: 50 \mathrm{~mm}$
e. Tinggi handle $: 150 \mathrm{~mm}$
f. Tinggi roda $\quad: 100 \mathrm{~mm}$ 


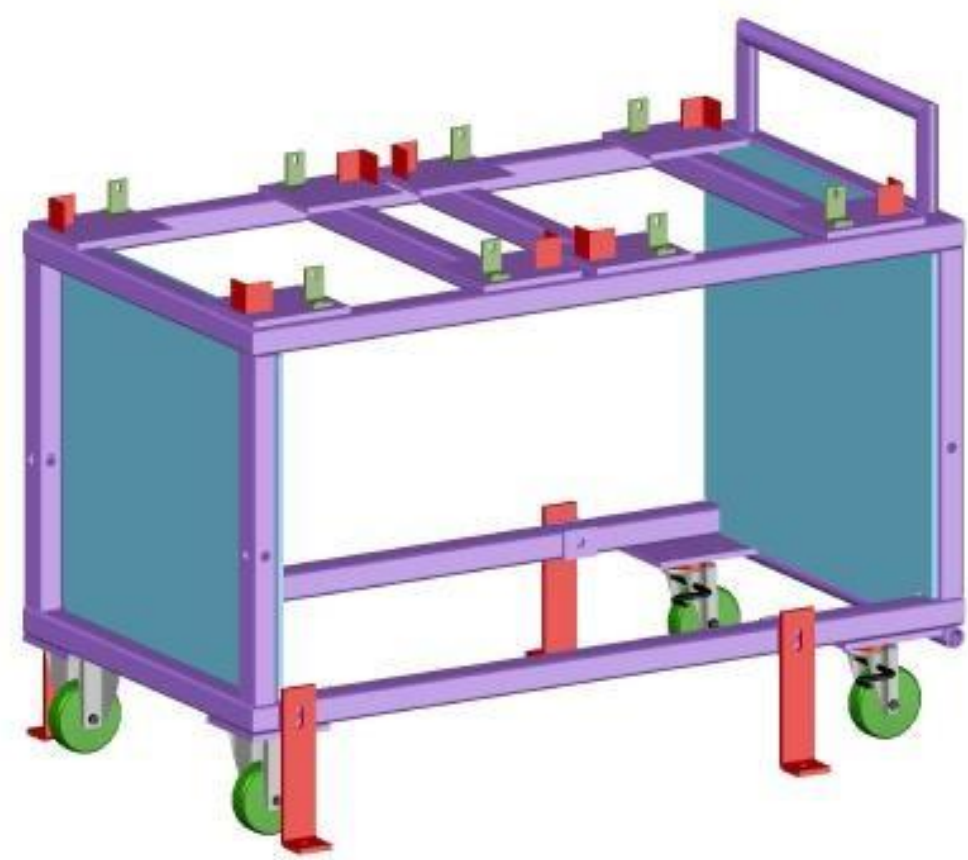

Gambar 5. 3D Model Checking Fixture Usulan

Sumber : Penulis, 2020

Setelah dilakukan perbaikan pada desain checking fixture terjadi perbaikan postur kerja pada proses pemeriksaan part mobil menggunakan checking fixture dimana diketahui bahwa skor RULA adalah 2 poin, berarti postur kerja yang dilakukan sudah berada pada kondisi nyaman. Skor LBA dapat dilihat besarnya gaya yang diperoleh sebesar $428 \mathrm{~N}$ dan masih berada dibawah batas normal yaitu sebesar 3400 N. Hasil evaluasi postur kerja dengan metode OWAS pada kondisi aktual operator checking fixture menunjukkan bahwa postur kerja operator berada dalam kondisi normal. Skor nilai OWAS berada pada critical posture dengan skor 1.

Tabel 12. Task analysis toolkit sesudah perbaikan

Sumber : Penulis, 2020

\begin{tabular}{lccc}
\hline Postur Tubuh & Nilai LBA & Nilai OWAS & Nilai Rula \\
\hline Memasang part mobil pada checking fixture & 428 & 1 & 2 \\
\hline
\end{tabular}

Berikut ini merupakan hasil rekapitulasi postur kerja aktual pada stasiun kerja pengecekan checking fixture setelah perbaikan. Terjadi penurunan nilai PEI menjadi 1,82 dari 2,73 yang menunjukkan bahwa perubahan desain checking fixture memiliki pengaruh terhadap postur tubuh penggunanya sehingga mengurangi resiko terjadinya cidera otot musculoskeletal

Tabel 13. Nilai PEI Sesudah Usulan

Sumber : Penulis, 2020

\begin{tabular}{lcccc}
\hline \multicolumn{1}{c}{ Postur Tubuh } & Nilai LBA & Nilai OWAS & Nilai Rula & Nilai PEI \\
\hline $\begin{array}{l}\text { Memasang dan memindahkan checking } \\
\text { fixture }\end{array}$ & 0.1305882 & 0.25 & 0.41 & 0.79 \\
\hline \multicolumn{2}{c}{ Rata-rata } & & 0.79 \\
\hline
\end{tabular}




\section{Desain For Assembly}

Dalam membuat alat checking fixture memerlukan proses perakitan atau assembly dimana kegiatan perakitan terdiri dari sub - sub assembly. Berikut adalah urutan kegiatan perakitan atau assembly checking fixture.

Tabel 14. Urutan Proses Perakitan Utama

Sumber : Penulis, 2020

\begin{tabular}{cl}
\hline No & \multicolumn{1}{c}{ Proses } \\
\hline 1 & Pasang sub-assembly handle \\
\hline 2 & Pasang sub-assembly frame atas \\
\hline 3 & Pasang sub-assembly frame bawah \\
\hline 4 & Pasang sub-assembly frame kiri \\
\hline 5 & Pasang sub-assembly frame kanan \\
\hline 6 & Pasang stopper \\
\hline 7 & Pasang sub-assembly frame \\
\hline 8 & Pasang plate atas \\
\hline 9 & Pasang plate bawah \\
\hline 10 & Pasang Handle \\
\hline 11 & Pasang cover kiri \\
\hline 12 & Pasang cover kanan \\
\hline 13 & Pasang Anchor \\
\hline 14 & Pasang Roda
\end{tabular}

Pada proses assembly keseluruhan terdapat komponen-komponen sub-assembly. Untuk mengetahui total waktu yang dibutuhkan dalam merakit keseluruhan komponen maka perlu dilakukan analisis design for assembly pada tiap-tiap sub-assembly. Terdapat 6 sub-assembly yaitu sub-assembly handle, sub-assembly frame atas, sub-assembly frame bawah, sub-assembly frame kiri, sub-assembly frame kanan dan sub-assembly stoper, sub-assembly frame, assembly handle. a. Sub-assembly

Tabel 15. Sub-Assembly

Sumber : Penulis, 2020

\begin{tabular}{lcccccc}
\hline \multirow{2}{*}{ Proses } & \multicolumn{3}{c}{ Jumlah Proses } & \multicolumn{3}{c}{ Total Waktu } \\
\cline { 2 - 7 } & ukur & potong & las & ukur & potong & las \\
\hline sub-assembly handle & 3 & 3 & 2 & 15 & 20 & 60 \\
\hline sub-assembly frame atas & 7 & 7 & 10 & 30 & 45 & 300 \\
\hline sub-assembly frame bawah & 4 & 4 & 4 & 20 & 25 & 160 \\
\hline sub-assembly frame kiri & 4 & 4 & 4 & 20 & 25 & 160 \\
\hline sub-assembly frame kanan & 4 & 4 & 4 & 20 & 25 & 160 \\
\hline sub-assembly stoper & 0 & 0 & 16 & 0 & 0 & 160 \\
\hline sub-assembly frame & 0 & 0 & 8 & 0 & 0 & 240 \\
\hline assembly handle & 0 & 0 & 2 & 0 & 0 & 60 \\
\hline
\end{tabular}

Kegiatan sub-assembly melalui 3 proses yaitu pengukuran pola, pemotongan besi dan pengelasan dengan total waktu pengukuran sebanyak 105 detik, total waktu pemotongan 140 detik, total waktu pengelasan 1300 detik. 
b. Assembly (Non-Machining)

\begin{tabular}{lccc}
\multicolumn{4}{c}{$\begin{array}{c}\text { Tabel 16. Assembly (Non-Machining) } \\
\text { Sumber : Penulis, 2020 }\end{array}$} \\
\hline No & Proses & Jumlah & $\begin{array}{c}\text { Total } \\
\text { Waktu } \\
\text { (s) }\end{array}$ \\
\hline 1 & Assembly anchor & 4 & 20 \\
\hline 2 & Assembly roda & 4 & 40 \\
\hline 3 & Assembly dolly \& CF & 2 & 80 \\
\hline & & Total & 140 \\
\hline
\end{tabular}

Total waktu assembly non-machining checking fixture adalah 140 detik dengan total kegiatan sebanyak 3 proses yaitu assembly anchor (4 unit), assembly roda (4 unit) dan assembly dolly \& checking fixture (2 unit).

\section{Design For Manufacturing}

Pada proses pembuatan checking fixture menggunakan beberapa mesin yaitu mesin potong, mesin las dan mesin spray gun. Terdapat 4 proses produksi checking fixture dengan 22 komponen pada proses pengukuran, 22 komponen pada proses pemotongan, 54 komponen pada proses pengelasan dan 2 komponen pada proses pengecatan.

Tabel 17. Ongkos mesin

Sumber : Penulis, 2020

\begin{tabular}{|c|c|c|c|c|c|c|}
\hline Jenis Proses & $\begin{array}{c}\text { Jumlah } \\
\text { Komponen }\end{array}$ & $\begin{array}{c}\text { Total Waktu } \\
\text { (s) }\end{array}$ & \multicolumn{2}{|c|}{ Biaya Mesin (menit) } & \multicolumn{2}{|r|}{ Ongkos } \\
\hline Pengukuran & 22 & 110 & $\mathrm{Rp}$ & 279.18 & $\mathrm{Rp}$ & $30,709.80$ \\
\hline Pemotongan & 22 & 140 & $\mathrm{Rp}$ & 279.18 & $\mathrm{Rp}$ & $39,085.20$ \\
\hline Pengelasan & 50 & 1300 & $\mathrm{Rp}$ & 279.18 & $\mathrm{Rp}$ & $362,934.00$ \\
\hline \multirow[t]{2}{*}{ Pengecatan } & 2 & 1200 & $\mathrm{Rp}$ & 279.18 & $\mathrm{Rp}$ & $335,016.00$ \\
\hline & & & & Total & $\mathrm{Rp}$ & $767,745.00$ \\
\hline
\end{tabular}

Total ongkos mesin dalam pembuatan satu unit checking fixture adalah Rp.767,745.00. Total ongkos mesin ini hanya untuk pembuatan dolly checking fixture usulan, tidak termasuk pembuatan bagian main checking fixture karena merupakan rahasia dari perusahaan pelanggan.

Tabel 18. Total ongkos

Sumber : Penulis, 2020

\begin{tabular}{llr}
\hline Proses & \multicolumn{2}{c}{ Ongkos } \\
\hline Material & $\mathrm{Rp}$ & $4,377,370.00$ \\
\hline Manufaktur & $\mathrm{Rp}$ & $767,745.00$ \\
\hline Total & $\mathrm{Rp}$ & $5,145,115.00$ \\
\hline
\end{tabular}




\section{Promodel}

Jumlah part mobil yang masuk ke dalam proses produksi sebesar 96 unit dengan waktu rata-rata perubahan sebesar 5 menit dan part mobil keluar sebesar 93 unit dengan waktu rata-rata perubahan sebesar 5 menit. Sebelum melakukan perbaikan pada desain checking fixture jumlah part mobil yang keluar adalah 84 dari 96 unit, dimana ada 12 unit part mobil yang tertunda selama proses produksi. Tetapi setelah dilakukan perbaikan ada peningkatan unit keluar yaitu sebanyak 9 unit menjadi 93 unit.

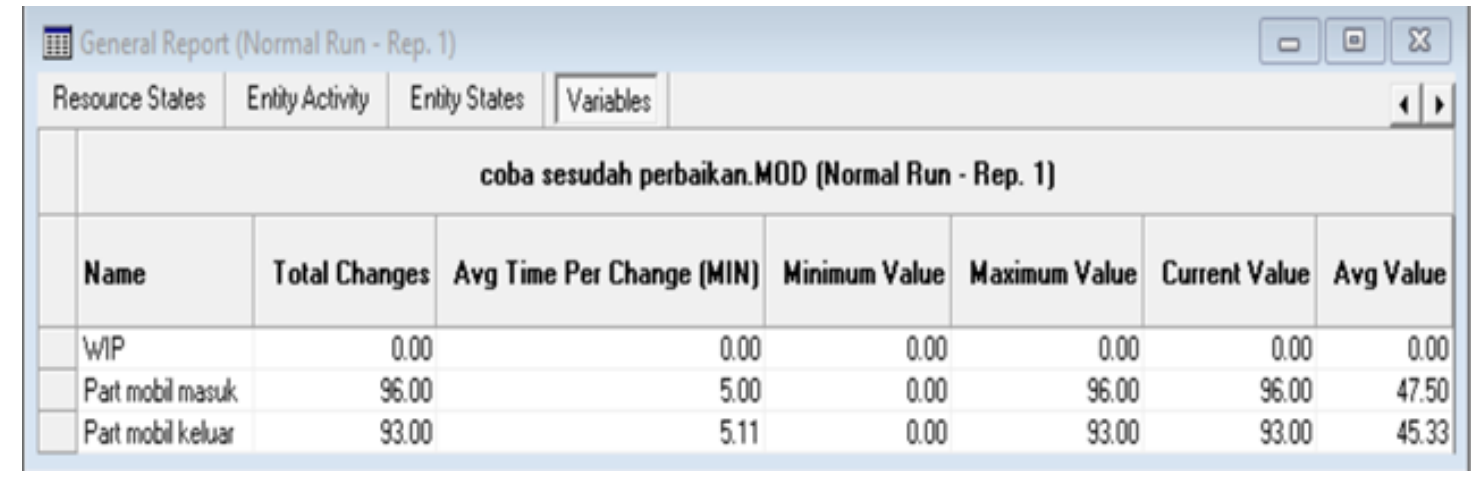

Gambar 6. Variabel sesudah perbaikan

Sumber : Penulis, 2020

Tabel 19. Perbandingan Promodel

Sumber : Penulis, 2020

\begin{tabular}{|c|c|c|c|c|c|}
\hline \multicolumn{6}{|c|}{ Perbandingan Promodel } \\
\hline Part Mobil & Hasil Produksi & $\begin{array}{l}\text { Produksi } \\
\text { Tertunda }\end{array}$ & Idle Time & $\begin{array}{l}\text { Average Time of } \\
\text { Production }\end{array}$ & Utilitas \\
\hline Sebelum & 92 unit & $19 \%$ & $76,95 \%$ & 17 menit & $23,05 \%$ \\
\hline Sesudah & 95 unit & $0,15 \%$ & $76,10 \%$ & 6 menit & $23,90 \%$ \\
\hline
\end{tabular}

\section{KESIMPULAN DAN SARAN}

\section{Kesimpulan}

Setelah dilakukan perubahan desain pada checking fixture terjadi penurunan nilai PEI, maka dapat dianalisis bahwa tingkat kenyamanan yang dirasakan oleh pengguna ketika melakukan proses pengecekan meningkat dan resiko gangguan cidera musculoskeletal menurun. Penurunan nilai PEI terjadi karena perubahan pada masing-masing nilai ergonomis pada aspek LBA, OWAS dan RULA. Dengan adanya perbaikan diharapkan mampu meningkatkan feedback positive dari konsumen. Desain usulan dapat meningkatkan hasil produksi menjadi 93 unit per 8 jam dari sebelumnya hanya 84 unit.

\section{Saran}

Selain memperhatikan desain checking fixture yang digunakan, para operator juga harus diajarkan posisi kerja yang benar. Hal ini dirasa penting agar desain checking fixture yang baru tidak menjadi sia-sia karena postur kerja yang dilakukan masih salah. Postur kerja yang benar akan memberikan kenyamanan dan kesehatan musculoskeletal bagi para operator. 


\section{REFERENSI}

Boothroyd G. (2011). Product Design For Manufacturing And Assembly. New York: Taylor \& Francis Group.

Caputo. F, Gironimo, G, D, Marzano, A. (2006). Ergonomic Optimization of a Manufacturing System Work Cell in a Virtual Environment. Acta Polytechnica, 46(5), 21-27

Hoffman, E. G. Jig And Fixture Design Fourth Edition. London: Delmar Publisher

Kuswana W.S. (2015). Antropometri Terapan Untuk Perancangan Sistem Kerja. Bandung: PT. Remaja Rosda Karya.

Jack User manual version 6.0 . (2008). California: Siemens PLM Software Inc.

Susanti L, Zadry. H. R, dan Yuliandra, B. (2015). Pengantar Ergonomi Industri. Padang: Universitas Andalas Press.

Tarwaka. (2011). Ergonomi Industri, Dasar- Dasar Pengetahuan Ergonomi dan Aplikasi di Tempat Kerja. Solo: Harapan Press Solo. 
USULAN DESAIN CHECKING FIXTURE DENGAN METODE

Hanna Setyoningsih, et.el.

DESIGN FOR MANUFACTURING AND ASSEMBLY YANG

ERGONOMIS 